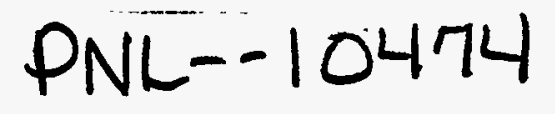

Baftelle

Pacific Northwest Laboratories

Date February 9, 1995 MAR $S T$

To RA Walters

From RA Pollari/tager

Subject 331 Building Drum Pressurization Incident Investiqation Report

Project Number. 331Drum. Inv Internal Distribution

WJ Apley LV Kimmel

WJ Bjorklund RR King

LE Braby WJ Madia

KC Brog HT Tilden

TD Chikalla JE Trevino.

MF Gillis MA Williams

DP Higby Operations Mgrs

GR Hoenes Res Fac Mgrs

BW Killand File/LB

Per your January 12, 1995 memo, "Investigation of 331 Barrel Incident in Room 175" (Exhibit A), the Investigation Board has completed its investigation of the incident and is submitting the attached report. The Investigation Board recommends that

- the Laboratory provide guidance for appropriate management and disposition of "legacy" materials. The guidance should, at a minimum, instruct staff that whenever unknown legacy materials are encountered, Laboratory Safety and Radiological Control staff should be contacted for a coordinated decision on proper handling and disposition of the material.

- ' the Laboratory's Operations Improvement Team include in its development of improvement initiatives the following as examples of inadequate line management implementation of PNL policy/procedure.

- Noncompliance with PNL-MA-8, Subsection 8.4.1, "When a project ends or an employee terminates, ensure that no waste remains unaccounted or unidentified."

- Noncompliance with PNL-MA-6, Article 351 and PNL-MA-7, Appendix J. Article 351 establishes the requirement for conducting critiques of radiological events; Appendix $J$ supplies the procedure.

- Noncompliance with PNL-MA-50, Section 4.3, "Conduct of Operations Assessment Checklist." This section states that "The assessment checklist is a record document that must be completed prior to initiation of work activities and (must be) appropriately maintained by the activity manager."

- the appropriate training classes be updated to include the message: "if a container is sealed and its contents are unknown or questionable - do not open. Contact Laboratory Safety for help." .

Staff need to be instructed on how to identify hazards. In addition to the training, staff should be provided with frequent and imaginative. examples of risks from the manager's assessment of operations, as well as examples from the PNL Lessons Learned Program. 
RA Walters

February 9, 1995

Page 2

- Lessons Learned articles be prepared for Laboratory-wide distribution and for distribution to the Hanford Lessons Learned Coordinator for Site-wide dissemination. At a minimum, the article needs to address Lessons Learned from 1) handling a sealed drum containing unknown contents, 2) selecting an inappropriate Radiological Work Permit (RWP), and 3) the potential for exposure to unknown chemicals during an evacuation.

The Lessons Learned article could be used to encourage staff to maintain a questioning attitude, and could also be used to inspire management to employ administrative aids (e.g., termination checklists) to guard against legacies left behind by retiring, transferring, or terminating staff.

- the Laboratory develop guidelines and an appropriate training program on "material spill response" requirements for a11 appropriate management and staff.

While the Investigation Board acknowledges. that such guidance is under development and will be incorporated into the building emergency procedures, it is recommended that this guidance resolve the following concerns:

- How and when is a determination made by the field (e.g., Building Emergency Director, Lab Monitor, ES\&H Officer, line management) that a spill is hazardous versus nonhazardous, taking into consideration the typa and quantity of material?

- If the field defers the above decision to Laboratory Safety, what

- interim actions should the field take until Laboratory Safety arrives?

- How will PNL "ensure...staff...understand their actions and responsibilities" before a spil1 occurs?

- Is the guidance practical and the training effective?

If you have any questions, please contact me at 376-4188.

RAP:mS

Attachment 


\section{INVESTIGATION OF DRUM PRESSURIZATION INCIDENT \\ IN THE 33.1 BUILDING, ROOM 175 \\ ON JANUARY 10, 1995}

FEBRUARY 1995

DISCLAIMER

This report was prepared as an account of work sponsored by an agency of the United States Government. Neither the United States Government nor any agency thereof, nor any of their employees, makes any warranty, express or implied, or assumes any legal liability or responsibility for the accuracy, completeness, or usefulness of any information, apparatus, product, or process disclosed, or represents that its use would not infringe privately owned rights. Reference herein to any specific commercial product, process, or service by trade name, trademark, manufacturer, or otherwise does not necessarily constitute or imply its endorsement, recommendation, or favoring by the United States Government or any agency thereof. The views and opinions of authors expressed herein do not necessarily state or reflect those of the United States Government or any agency thereof.

PACIFIC NORTHWEST LABORATORY:

RICHLAND, WASHINGTON 



\section{DISCLAIMER}

Portions of this document may be illegible in electronic image products. Images are produced from the best available original document. 


\section{CONTENTS}

SCOPE ........................... 1

SUMMARY ............................ 1

FACTS SECTION . . . . . . . . . . . . . . . . 2

BACKGROUND .......................... . . . . 2

THE EVENT ......................... 4

RESPONSE TO THE EVENT .................. 5

ANALYSIS SECTION ..................... 8

THE EVENT ......................... 8

POSSIBLE SCENARIOS ..................... 9

ROOT CAUSE METHODOLOGY . . . . . . . . . . . . . . . 11

CONCLUSIONS . . . . . . . . . . . . . . . . . . 11

GOOD PRACTICES .................... 11

FINDINGS ....................... . 12

CAUSAL FACTORS ................... . . . 13

Direct Cause .. . . . . . . . . . . . . . 13

Contributing Causes ................. 14

Root Cause ................... 14

JUDGEMENT OF NEEDS .................... . . 15

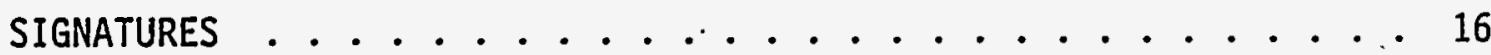




\section{EXHIBITS}
A. APPOINTMENT LETTER
B. ROOM DIAGRAM
C. PHOTOGRAPHS
D. NDA REPORT
E. RADIOLOGICAL SURVEY REPORT
F. PNL 2400 REPORT
G. RWPS
H. REFERENCES
Individuals Interviewed
Documents Reviewed 


\section{SCOPE}

On January 10, 1995, at approximately 0830 hours, a pressurized drum incident occurred at the 331 Building, Room 175. On January 12, 1995, the Manager of the Life Sciences Center appointed members to an Investigation Board to investigate the incident (see Exhibit $A$ ).

This incident was initially categorized as an off-Normal Occurrence, but was later elevated to an Unusual Occurrence by the Occurrence Classifier. The scope of this investigation was to

- employ a formal method of root cause analysis, identify the methodology, and report the results of the analysis, fully explaining the technical elements of the causal sequence along with a description of the barriers that should have or could have prevented the occurrence.

During the course of the investigation, the scene of the event was not accessible. Therefore, the investigation relied primarily on testimony from staff members directly involved and their management. In addition, other outside professionals were also consulted (see Exhibit H). ' The Investigation Board visited the previous location of the drum, 331A Building, Room 9; Room 173 , which fronts room 175, was also visited. The Investigation Board reviewed selected documents, which are also listed in Exhibit $H$.

\section{SUMMARY}

The 331 Building, also known as Life Science Laboratory 1, is a U.S. Department of Energy Facility operated by Battelle Memorial Institute. The 331 Building is the largest of ten buildings which comprise the 331 Facility.

On December 30,1994 , a 55-gallon black steel drum located in the $331 \mathrm{~A}$ Building, Room 9, was discovered to have rust on its base rim.

On January 5, 1995, the drum was brought into the 331 Building, Room 175, to be opened so that the contents could be inventoried and repackaged in a new drum.

On January 10, 1995, the Hazardous Materials Coordinator (HMC) and a volunteer (a senior research scientist from the.building) gathered to start the inventorying and repackaging task. Very shortly thereafter, the researcher, HMC, and the attending Radiological Control Technologist (RCT) were involved in a potentially dangerous situation when the lid blew off the pressurized drum. The lid presumably struck an overhead light, breaking its cover and bulb, and landed approximately eight feet away. Four 120-mi bottles were ejected from the drum; two of the bottles were empty and two contained liquid, some of which spilled out onto the floor. The floor of the room was found to be contaminated, as were the personal shoes of the HMC and researcher. No one 
was injured and there was no spread of contamination outside the room. Later in the morning, the RCT reentered Room 175, stabilized the spilled 1iquid, upgraded the posting for the room, and locked the door. During this reentry, the RCT was outfitted with the Personnel Protective Equipment (PPE) specified by Radiological Work Permit (RWP) \#PNL-6 (Exhibit.G) and as supplemented by the Manager of Radiological Control Operations. The Manager of the Life Sciences Center then appointed an Investigation Board to investigate the incident.

Given that the drum was already pressurized and that the (controllable) incident was actually the inadvertent release of that pressure, the Investigation Board concluded that the direct cause of the incident was inadequate content in training; i.e., those involved proceeded with opening a sealed container without knowledge of the contents because their training did not identify the specific risk (potential pressurization without obvious physical indicators, caused by unknown contents).

A significant contributing cause was "inadequate procedure." The selected RWP (RWP \#331-32, Rev.16) was originally written for the routine "shipping, receiving, and unpacking of radioactive shipments." While it is clearly understood that RWPs are not procedures, the selection of this RWP effectually circumvented the conduct of operations assessment checklist. Had the uniqueness of the work activity been recognized, the appropriate work controls may have been established. (Other contributing causes were also identified. They are listed on page 15.)

The root cause for this incident is attributed to "management problem - policy not adequately defined, disseminated, enforced." A policy on how the Laboratory should manage legacy and/or unknown materials is not clearly defined nor is guidance provided to the field. With the appropriate policy, guidance, and corresponding training, the Laboratory should be able to manage its legacy issues and avoid a recurrence of this type of incident.

\section{FACTS SECTION}

This section contains a description of background information on 331 Building operations that led to the drum pressurization, the incident, and the response to the incident.

\section{BACKGROUND}

Approximately three years ago, the Biology and Chemistry Department appointed one of its staff members as the Department's HMC. Since that time, the Department has demonstrated aggressiveness in its pursuit to eliminate unneeded materials located within the 331 Facility complex. Notable highlights of this campaign include the disposal of 40 used High Efficient Particulate Air (HEPA) filters from the second floor mechanical room, five drums of unknown 1 iquids that had been located on the 331 dock, and five or 
six $4 \times 4 \times 8 \mathrm{ft}$ plywood boxes of unneeded research materials that had been stored at 331C, the 331 Facility Warehouse.

In June 1992, during this cleanout program, the RCT discovered a black, 17H, 55-gallon steel drum in Building 331A, Room 9. Taped to the top of the drum 1id was a Nondestructive Assay (NDA) report (Exhibit D) dated October 17, 1989. The report did not include an identification tracking number. The drum was the type used for disposal of "dry" low-level radioactive material and is thought to have originated in the 1980s. The exact contents of the drum were unknown.

When the drum was discovered, management recognized that it would have to be opened so the contents could be inventoried and evaluated for subsequent retention or disposal. Management gave this task a lower priority, however, after 1) considering the drum's probable contents (low-level radioactive material; an assumption based on knowledge of past operations, which was supported by its low weight and the absence of "sloshing"), and 2) recognizing more pressing regulatory waste disposal issues. Another factor contributing to this decision was that the drum was being stored inside Room 9, rather than on a dock where it would be exposed to the elements.

On December 30, 1994, two-and-one-half years after management's decision, the RCT assigned to the 331 Facility was conducting a routine radiological survey of the Building 331A, Room 9. This survey would also serve as a re-posting survey to change the room's designation to a Radiological Control Área only. Because the room is so small $(-5 \times 8 \mathrm{ft})$, the RCT had to move the drum out of the way in order to survey the face of the hood. At this time, the RCT noticed a rust ring had formed on the floor below the drum. As the drum was moved, a slight rocking motion was noticed. The RCT promptly reported the situation to the HMC, who decided that the drum would have to be emptied and the contents inventoried and repackaged. The decision was made to move the drum into Room 175, where this work could be performed under controlled conditions. On January 5, 1995, three working days after discovery of the drum, a serviceman moved the drum into the doorway of Room 175 and the HMC positioned the drum in front of the fume hood nearest the door. (At 0400 hours, the temperature was $-9^{\circ} \mathrm{C}$ and the humidity was 90 percent. The high temperature for that day was $-1^{\circ} \mathrm{C}$ with 48 percent humidity.)

Room 175 was chosen as a location for this work because it 1) is a Radiation Area/Radioactive Material Area, 2) has no floor drains, 3) is equipped with two fume hoods with double HEPA filtration, 4) is maintained with a negative air pressure relative to the hallway, 5) is typically used. for the receiving and unpacking of radioactive shipments, and 6) has been used for other drum repackaging activities. For example, drums of waste containing Phosphorus-32 $(P-32)$, which had been held in storage for up to a year to allow natural decay, were brought to Room 175 for repackaging for the purpose of waste minimization. In addition, drums of low-level waste of known contents were also repackaged in the room due to changes in waste acceptance criteria. 
The RWP that governs these activities is RWP \#331-32, Rev.16 (see Exhibit G). The scope of this RWP includes 1) entry for observation, 2) transferring materials and containers between Rooms $175 \mathrm{~A}$ and 175,3$)$ shipping and receiving radioactive shipments, and 4) unpacking radioactive shipments.

In preparing for the work, an empty 55-gallon blue drum was positioned in front of the second fume hood, up against the back wall, to receive the materials that would be removed from the black drum.

Based on past practices and the expectation that the drum contained dry materials, the HMC and RCT decided that RWP \#331-32 would be the applicable permit for the intended opening, inventorying, and repackaging of the drum.

On the morning of the event ( -0815 hours on January 10,1995$)$, the RCT collected a routine air sample from the room and took a dose reading at the drum: the rate was $<0.5 \mathrm{mrem} / \mathrm{hr}$. A direct reading from the drum surface read 10,000 disintegration per minute $(\mathrm{dpm})$.

During the course of the staff interviews, various statements were made that suggested the drum may have been deformed.

- The RCT noted that while moving the drum around in Room 9 (December 30), it wobbled like it had an uneven bottom or was on an uneven surface.

- The HMC stated that the drum lid appeared to be slightly bulged on the morning of January 10. During a subsequent visit to the $331 \mathrm{~A}$ Building, the HMC pointed out a similarly bulged lid on a drum sitting on the dock. The lid on this drum did not appear to the Investigation Board to be bulged.

- During the researcher's interview, the drum was described as sitting "uneven."

\section{THE EVENT}

Shortly after the RCT collected the air sample, the HMC, RCT, and a resident senior research scientist (who volunteered to assist the HMC) gathered for the repackaging task.

At the time of the incident ( -0830 hours), the HMC was positioned in front of and facing the work bench. The researcher, who opened the drum, was on the opposite side between the black drum and the new blue drum. The RCT was at the doorway between Rooms 175 and 173 , receiving a lab coat from another researcher who was in Room 173. The researcher in Room 173 was waiting to neutralize samples in one of the hoods in Room 175. This researcher had just returned to Room 173 after retrieving more lab coats, as there were only two lab coats in Room 175. 
Both. the HMC and assisting researcher, who were in Room 175, were wearing the PPE specified in RWP \#331-32: 1ab coat, gloves, and safety glasses. (See Exhibit $B$ for position of staff.)

In preparation to remove the lid, the researcher unscrewed the bolt from the ring holding the lid (there was no locking nut on the bolt). When the ring could not be removed by hand, the researcher used a hammer to tap the ring and break it loose from the rim. It was at this time that pressure within the drum was released; the lid and ring were blown off and four 120-ml bottles from within the drum were cast out onto the floor. None of the bottles were broken.

The lid landed on the floor about eight feet from the drum. The ring settled on the floor near the base of the drum. The four bottles landed on the floor at various locations within four feet of the drum. Two of the bottles leaked a total of 20 to $30 \mathrm{ml}$ of liquid, which is believed to be two normal nitric acid $\left(2 \mathrm{~N} \mathrm{HNO}_{3}\right)$, an assumption based on knowledge of past operations. The other two bottles were empty. (See Exhibit $C$ for photographs' of the scene of the event and Exhibit $E$ for radiological survey results.)

During this event, the drum lid presumabiy struck the overhead light fixture (the ceiling is about eight feet high). The floor was showered with broken pieces from the light cover and bulb (see Exhibit C). A cloud of particulate was also immediately visible. It is believed the cloud was composed of dust from the light cover and the powdery substance from inside the fluorescent bulb.

\section{RESPONSE TO EVENT}

A verbal exchange confirmed that no one was injured.

The HMC and the researcher proceeded to the exit. The HMC left the room to self survey first, while the researcher remained in Room 175, near the entrance. To get to this position; the researcher had to pass by the drum, which the researcher did by purposefully taking the path opposite the airstream from the open drum to the fume hood.

While still in Room 175, the HMC removed PPE, which was bagged and placed on the floor inside the door of Room 175. The HMC then exited to Room 173 and stepped onto the hand and foot counter. The counter alarmed for the right shoe.

During this time, the researcher who had been waiting to use one of the hoods left the area to report the incident to the Manager of Biology and Chemistry (the responsible line manager); the Manager in turn contacted the 0ccurrence Classifier and the Single Point Contact. That call was received at 0834 hours, according to the 2400 Report (see Exhibit F). 
Using a portable instrument, the RCT performed a whole body frisk of the HMC and discovered an alpha contamination reading of $2,000 \mathrm{dpm}$ on the bottom of one shoe. After removing both shoes, the HMC performed another hand and foot counter survey, this time with negative results. The contaminated shoe and the clean shoe were bagged and placed inside the door of Room 175.

While the HMC was being surveyed, the researcher used a phone in Room 175 to call and request that the RCT's supervisor come to the scene of the event.

Next, while still at the door, the researcher removed all PPE and a whole body frisk was performed by the RCT using the portable instrument. This survey found alpha contamination on the soles of both shoes: 10,000 and 5,000 dpm. These shoes were also bagged and placed inside the door of Room 175. The assisting researcher then performed a self survey on the hand and foot counter with negative results.

At about this time, the RCT's supervisor and the Alternate Building Emergency Director (BED) arrived at the scene. The Alternate BED is also the line manager responsible for operations in Room 175.

After the personnel surveys were completed, the RCT took nasal smears from both the HMC and the researcher. There were no readings above action levels.

The next action taken was to close and lock the door to Room 175. The room is maintained on negative air pressure and is equipped with double HEPA filter exhaust. (When checked by Air Balance staff on January 19, 1995, the negative air pressure was still being maintained.)

At -0944 hours, the RCT set up to collect an air sample from within Room 173, near the entrance to Room 175. The sample was timed out at 1040 hours.

It was around this time that both the Manager of Radiological Control Operations and the primary BED arrived at the scene of the event.

An informal plan was conceived for reentering Room 175 in order to stabilize the spilled liquid and collect an air sample. RWP \#PNL-6 was selected to govern the reentry. The stipulated PPE included head cover with air-purifying respirator (equipped with HEPA and acid/gas filtering cartridges), two sets of surgeons gloves plus acid resistant gloves, two sets of coveralls, and. shoe covers. The adequacy of the PPE was confirmed by the Manager of Radiological Control Operations; who has RCRA/CERCLA experience, including 40-hour HAZWOPER training. The choice of the acid/gas filtering cartridges for the respirator was based on knowledge of past operations, indicating that the liquid was.

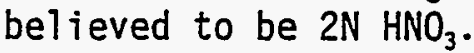

Incidental to this event was that at about 0815 hours on the morning of the event, the RCT collected an air sample from Room 175 as part of the morning routine. That air sample should serve as a timely benchmark for the recovery and restoration activities which are under development. 
At approximately 1050 hours, the RCT reentered Room 175.

The RCT's first task was to remove the air sample (that had been started at 0815 hours) while the gloves were still clean/uncontaminated. The air sample was sent to the Counting Lab at the 3745 Building.

After removing the sample, the RCT picked up the bagged PPE and shoes and discarded them in a waste drum located in the room. The lab coats were not sent to Laundry since the incident involved alpha contamination and PPE contaminated with alpha is not accepted at the Laundry.

The RCT then 1) picked up the four 120-mi bottles and returned them to the cardboard container inside the drum, 2) put the drum ring in a plastic bag and set it on the floor between the drum and the hood, 3) wiped up the spilled liquid from the floor (using three set of three Terri Towels, one swipe apiece) and placed the towels in the drum, 4) picked up the largest pieces of broken light cover and bulb, placing them in the new drum, 5) used a masslinn mop head to sweep up remaining broken pieces of light cover/buib and placed the pieces in a new drum, and 6) handed the masslinn miop through the door to a second RCT in Room.173, who surveyed it (see Exhibit E, this was smear M2). The RCT in Room 175 then checked the floor once again, going over the areas with a clean Terri Towel (which was also placed in the subject drum). For the final task, the RCT took tech smears 1 through 5 (see Exhibit E) and handed them to the second RCT for survey.

To exit Room 175, the RCT placed two sheets of plastic on the floor near the door (inside Room 175) to stand on while removing all PPE. The RCT stepped out of the room to self survey with portable instruments and the hand and foot counter. No contamination was detected.

While the RCT was working in Room 175, the second RCT in Room 173 took a masslinn smear M1 from the floor of Room 175 (see Exhibit E) by reaching across the threshold of the door. The survey of this smear detected alpha contamination of $750 \mathrm{dpm}$. The other massiinn smear sample recorded alpha contamination of 25,000 dpm and beta-gamma of 5,000 dpm.

Of the five tech smears, two were collected from the bench top, one from the ledge of the nearest hood, and two from the floor near the drum. Oniy the tech smears taken from the floor produced any. detectable levels of contamination. The most contaminated of the two detected alpha contamination of $150,000 \mathrm{dpm}$ and beta-gamma of $5,000 \mathrm{dpm}$.

A11 smear samples, masslinn mops, and tech smears were double-bagged and placed on the floor inside Room 175.

The door to Room 175 was closed and locked and the room was posted as an Airborne Radioactivity Area and High Contamination Area.

The RCT finished the Radiological Survey Report at 1145 hours. 
Due to equipment problems, the air sample that was sent to the Counting Lab was forwarded to the 329 Building for analysis. Since the 329 Building equipment is set up to provide readings of environmental concern, the results indicated only that there was a slight peak in activity. This information was subsequently used for the decision to send the HMC, researcher, and the RCT for a Whole Body Count (WBC). Not all air samples had been analyzed and reported at that time; counting data was not available for the air sample that had been started at 0815 hours and pulled when the RCT reentered the room at 1050 hours.

On January 10, all of the available information was gathered and a "fact sheet" was published.

On January 11, the Manager of Biology and Chemistry issued a "required reading" message to all 331 Building occupants to communicate immediate Lessons Learned. On January 13, the Director of Facilities and Operations called for the release of a formal "Heads Up" detailing the immediate Lessons Learned to all Level 1 organizations. It was transmitted on January 17.

On January 13, 1995, three days after the incident, the HMC, researcher, and RCT were sent to the WBC for complete surveys.

On Saturday, January 14, a technician from PNL Dose Assessment delivered fecal sample packages to the RCT and the researcher at their homes. A fecal sample kit was delivered to the HMC's home on Monday, January 16, since the HMC's home could not be located during the weekend.

Management also conducted a search for other sealed containers with unknown contents.

The Investigation Board has not looked into the results of the air sample, the $W B C$, or the fecal samples.

To date, the room has not been reentered for recovery operations and the Investigation Board has not physically inspected the room and the evidence contained in the room.

\section{ANALYSIS SECTION}

\section{THE EVENT}

The sudden depressurization of the drum corresponded to the exact moment the researcher tapped the retaining ring with the hammer. The fact that something, presumably the drum $1 \mathrm{id}$, was launched into the overhead light fixture and that the lid landed eight feet away suggests that the pressurization was substantial. The physical evidence at the scene has not been inspected (e.g., possible drum deformities) and the cause of the pressurization has not yet been determined. However, potential contributing 
factors include temperature change (outside to inside temperature change of almost $25^{\circ} \mathrm{C}$ ), radiolysis, possible organic decomposition and chemical reaction, or a combination of these factors.

The damage caused by the incident amounted to a broken light cover and fluorescent bulb. The extent of the damage appears relatively minor.

While no physical harm resulted from this incident, some potential for injury existed from the release of energy and/or j11ness from exposure to the chemicals.

Although knowledge of past operations led to a reasonable assumption regarding the drums contents (that they were dry materials), the absence of an actual inventory sheet should have established the contents as unknown. As an unknown, it should have been treated as a unique work activity rather than as routine.

The NDA Report identified isotopes of Pu present in the drum, there is some concern that the quantities could be regarded as transuranic (TRU). However, there is insufficient data available to make that determination or even to. verify that this NDA report belonged to this drum (i.e., there was no identification tracking number to connect the NDA results with this specific drum). It is also impossible at this time to determine if the contents constitute material balance area quantities of nuclear material.

Furthermore, there is insufficient data available to determine the classification for this waste. Determination will rely on analysis of the liquid(s), including radiolytic and chemical analysis.

\section{POSSIBLE SCENARIOS}

Given the current information, some possible scenarios exist that may account for the pressurization of this drum.

One scenario is radiolytic decomposition of plastic liner (see Exhibit C plastic liner shows signs of deterioration). This concern is illustrated by the following, which was extracted from a 1993 Defense Program (DP) Safety Action Letter (SAL):

"DP facility management and personnel (were alerted to) potential safety concerns associated with the potential pressurization of stored waste drums containing transuranic (TRU) waste in contact with hydrogenous materials." (That is, materials capable of generating hydrogen through radiolytic degradation.)

The SAL presented two concerns: "...radiolytic pressurization of waste drums with nonvented lids which contain TRU and-organic materials" and 
"waste drums having vent filters may be susceptible to pressurization if significant corrosion of the vent filters has occurred."

The SAL also says, "Many organic materials can decompose when exposed to radiation. In particular, alpha radiolysis of organics in TRU wastes can cause significant gas generation and possible drum pressurization. Another safety concern is the potential generation of flammable or explosive mixtures of gases in waste drums containing TRUs and organic materials. For example, the radiolytic decomposition of plastic waste packages found in many DP waste storage drums can produce hydrogen hazards to workers and the environment. Venting of waste drums may alleviate these potential hazards."

Although the materials present in the drum in Room 175 are most likely not TRU, the probable decomposition in that drum, coupled with the change in atmospheric pressure (outside to inside temperature change of almost $25^{\circ} \mathrm{C}$ ), may have been sufficient to cause the 331 Building drum pressurization incident.

Also possible in this scenario is that the drum contained low-level -radioactive material and was air-tight may have been enough. Although the details are little sketchy, the following example illustrates this point (reference: Westinghouse Hanford Occurrence Report RL--WHC-WHC200EM-19920051):

On August 28, 1992, PEDF personnel noted that one of their 55-gallon drums of waste was bulging. The emergency response team was summoned. "The team tried to drill through the drum... with no success. The drum was moved into the facility (2724-W) and opened." (the report does not mention how drum was opened.) The drum "displayed some force propelling the drum lid upward discharging sand and other drum contents. HAZMAT Team personnel performed a sniffing operation with negative results."

"When the lid was off the inside contents (were surveyed and produced a reading of) $20,000 \mathrm{dpm}$." The emitter was not specified in the report.

"The method of packaging of (low-level radioactive waste) drums caused the metal drums to be air-tight along with a chemical or heat reaction of drum contents...could have caused an internal gas buildup within the drums. With this combination, an internal reaction caused an outward distortion (bulging) of the drums lid."

Another conceivable scenario is that the drum contains some unexpected and incompatible chemicals. This will be determined after recovery and restoration activities begin and the contents of the drum are analyzed. 
Still another possibility, organic decomposition, can be drawn from the following event that happen at Oak Ridge National Laboratory last year (reference Martin Marietta Occurrence Report ORO--MMES-Y12WASTE-1994-0001):

"On Apri1 5, 1994,... a metal 1id on a sealed 55-gallon drum containing soiled gloves, rags, and filters was blown off under pressure which had built up inside the container over an extended period of time. This incident occurred as the 'drum ring' ... was being adjusted by two...employees.... The metal lid was blown approximately 14 feet into the air, landing eight feet. from the drum. The decaying process of the organic material (sludge) which covered the contents of the container created a methane gas, causing the drum to become pressurized."

\section{ROOT CAUSE METHODOLOGY}

Causal factors charting was the primary analysis tool used. In addition, a Causal Analysis Worksheet (from PNL-MA-41, PNL ES\&H Management Self-Assessment Program) was used to augment the causal factors analysis.

\section{CONCLUSTONS}

\section{GOOD PRACTICES}

The Investigation Board acknowledges the significant and careful work that the HMC has accomplished over the past few years. The record would appear to . support a significant contribution to the Department and Laboratory with no prior incidents and should not go unrecognized.

In addition, the RCT's good survey routine is credited with the initial discovery of the drum in June 1992, which was brought to the attention of management who acknowledged the need to inventory and repackage the contents.

Many of the immediate actions taken at the scene of the incident were commendable: 1) concern expressed for personal safety, 2) foresight to stay out of an airstream between open drum and fume hood while exiting the room, 3) orderly and thorough personnel radiation surveys, including use of makeshift step-off pads, 4) timely notification to management, including BED, and the RCT supervisor and manager, 5) the call to Single Point Contact, 6) efforts to control the spill (to wipe it up before it dried in order to avoid dispersal of alpha contamination); and 7) securing and posting Room 175.

Timely, prudent, and appropriate actions were also demonstrated by management's decision to prepare and disseminate both a "required reading" message to building occupants and a Lessons Learned "Heads Up" across the Laboratory and to conduct a hunt for other sealed containers with unknown contents. 


\section{FINDINGS}

- Sufficient information was not available on the contents of the drum to support a decision on how to proceed with repackaging.

Ownership of the drum was unknown, the date the drum was originally packaged and sealed was unknown, the specific inventory was unknown, and the drum's NDA report did not link its results with this specific drum by an identification number.

- Management has not been in compliance with PNL-MA-8, Waste Management \& Environmental Compliance, Subsection 8.4.1.

This Subsection lists the responsibilities of Line Managers/Project Managers with regards to Hazardous Waste. It states, "When a project ends or an employee terminates, ensure that no waste remains unaccounted or unidentified."

- No conduct of operations assessment checklist was completed and documented for this work activity. If a checklist had been used, the need for at least a Job Hazard Breakdown (JHB) could have been recognized and the risk assessed.

As a result, the wrong RWP (RWP \#331-32, Rev.16) was selected.

RWP \#331-32, Rev.16, was written for shipping, receiving, and unpacking radioactive shipments (i.e., known commodities) and had been used in the past to permit repackaging waste from drums with known contents (e.g., drums of waste containing $P-32$ ).

However, regardless of past practices, relying on the existing RWP was inappropriate for an unknown commodity. A special RWP and work document (e.g., a Safe Operating Procedure or JHB) were needed for this unique task. That need could have been identified through a conduct of operations assessment checklist.

- The immediate actions taken were deficient. The researcher did not exit Room 175 immediately following the incident.

A11 workers should have evacuated Room 175. The researcher should have at least stepped into Room 173 to reduce potential radiological and chemical exposure.

Although, it was probably good judgement to theorize that the spilled liquids were $2 \mathrm{~N} \mathrm{HNO}_{3}$ (since staff present were familiar with the type of bottles involyed), there were still uncertainties regarding the remainder of the drum's contents (contents that were not known or in view). To err on the side for worker's safety would have been a preferable ALARA approach. 
- Communication between the event scene and the Single Point Contact was less than adequate.

The incident was initially thought to be a radiological event. As a result, when the Laboratory Safety contact was made no indication was given that would alert the Laboratory Safety contact that an Industrial Hygienist, Waste Management, or Environmental Compliance professional was needed at the scene.

- Initial reentry planning was less than adequate.

Since the Laboratory Safety professionals were not included in the event response (see previous finding), the reentry decision lacked input and approval for hazardous chemical concerns.

This oversight, however, could have been remedied if the Building Emergency Plan (BEP) detailed its requirement to "take steps to contain (the spi11) if possible." Specifically, the BEP needs to direct occupants to contact Laboratory Safety when the spilled liquid is unknown. It would also be helpful if the BEP addressed -- in what situations are staff to take steps? In what situations. should they not take steps? And what would prompt them to contact others (e.g., PNL Waste Management, Hanford Fire Department HAZMAT response) for assistance?

- Event critique was less than adequate. .

A7though information was informaliy gathered and a "fact sheet" was distributed (and the manager who would have been responsible for leading the critique was involved), a formal critique was not conducted, as required by PNL-MA- 6 , and the information gathering process did not benefit from the involvement of other disciplines and procedural guidelines, which are specified in PNL-MA-7, Appendix J.

\section{CAUSAL FACTORS}

\section{Direct Cause}

- Training Deficiency - Inadequate Content (5000.3B Cause Code 5C)

Although it is probable that the pressurization of the drum was caused by a combination of atmospheric changes and organic decomposition (as evidenced by the condition of the plastic liner), the incident occurred because no one was able to recognize. and anticipate the hazard. The drum lid was opened because no one had instructed the workers about what to do when one encounters a sealed container with unknown, or even questionable, contents. Therefore, training related to hazards awareness is found to be

- Tess than adequate. 


\section{Contributing Cause(s)}

- Personnel Problem - Inattention to Detait (5000.3B Cause Code 3B)

When the drum was packaged, inattention to detail on the part of the original packer resulted in the lack of sufficient labeling.

No recommendation/corrective action is needed for this identified cause since current procedures present adequate requirements to protect against the generation of new legacies.

Note: Legacy materials are defined as those materials that were left over from past projects/operations that are not identified or no longer have funding to support continued use or disposal.

- Inadequate Admịnistrative Control (5000.3B Cause code 6A)

Past practices allowed generation of legacy materials without proper packaging and/or inventorying.

In this specific case, management's failure to comply with PNL-MA8. Subsection 8.4.1, resulted in the drum not being disposed of or properly labeled before accountability was lost through staff termination.

- Hork Organization/Planning Deficiency (5000.38 Cause Code 6B)

This work activity did not receive the level of planning needed for a drum containing unknown contents. Management needs to have in place a mechanism/understanding with staff to ensure that unique, first-time tasks are identified as such, and management is given the opportunity to help staff plan the work to avoid potential risks. This mechanism/understanding must also provide some assurance to management that work activities are being performed under the appropriate procedures. Familiarity with and use of the conduct of operations assessment checklist would have been beneficial.

\section{Root Cause}

- Policy Not Adequately Defined \& Disseminated (5000.3B Cause Code 6E)

The Laboratory lacks a policy regarding the handling of sealed containers with unknown or questionable contents.

Legacy issues are certainly not an uncommon phenomenon throughout industry. In FY 1994, several thousand dollars were set aside to fund a program aimed at reducing the Laboratory's holdings of "Tegacy waste." 
Since legacy issues have been and stili are a management concern, the Laboratory is deficient in not having developed a plan for dealing with sealed containers and their potential hazards. If such guidance had been published and the training related to hazardous materials issues upgraded, the HMC and assisting researcher would have possessed the information needed to avoid this incident and potential exposure to unknown chemicals that may be in the drum.

\section{JUDGEMENT OF NEEDS}

The goal of this Investigation Board is to provide the Laboratory with information that can help management and staff avoid a recurrence of this or a similar incident. Toward that end, the Investigation Board issues the following judgement of needs:

The Laboratory (not exclusively the Life Sciences Center) needs to establish a policy and provide guidance on how it will manage and dispose of both known and unknown legacy materials. Without such guidance, the Laboratory is unable to consistently and effectively deal with and minimize risks to staff, the facilities, and the environment. The result is that conduct of operations assessments are not triggered, appropriate procedures and training are not provided, and event response actions (e.g., spill response and amelioration) may be inappropriate or incomplete. 
BOARD MEMBERS:

EX OFFICIO:
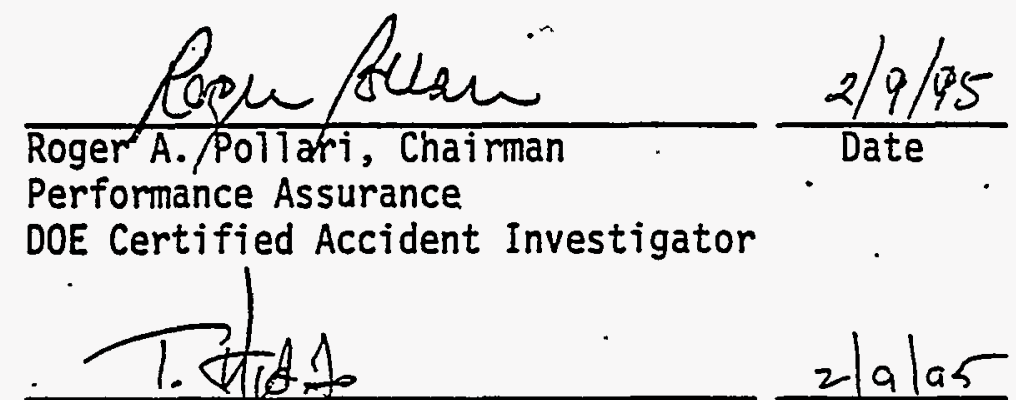

Tatșuya Hikido, Sr. Program Mgr

$\frac{2 \operatorname{lala5}}{\text { Date }}$ Performance Assurance

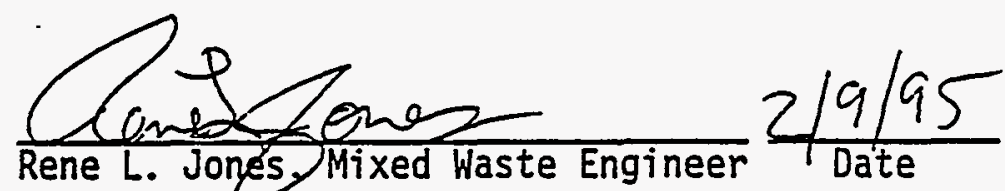
Waste Management Section Laboratory Safety Department

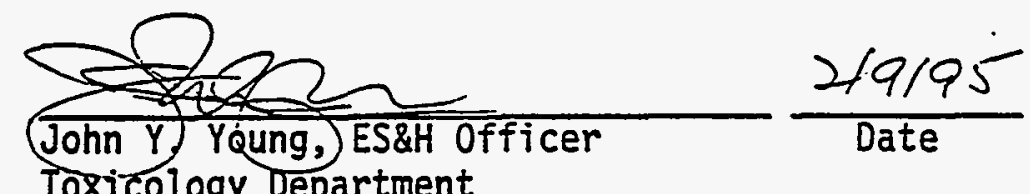
Toxicology Department

Life Sciences Center

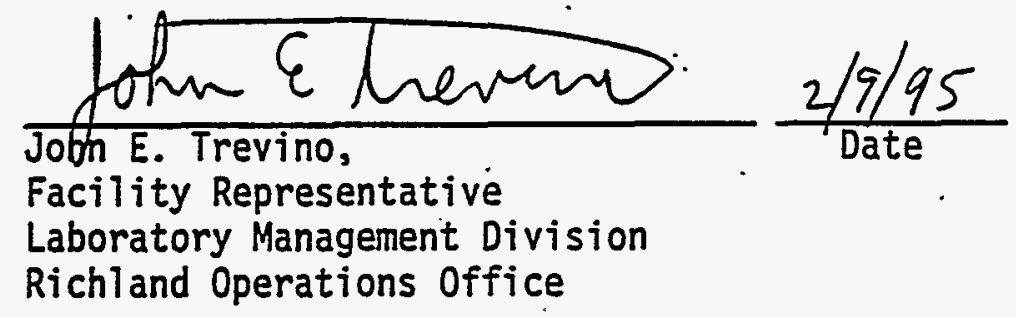


EXHIBIT A .

\section{INVESTIGATION BOARD APPOINTMENT LETTER}




\begin{tabular}{|c|c|c|}
\hline Date & January 12, 1995 & $\begin{array}{l}\text { KC Brog } \\
\text { TD Chikalla }\end{array}$ \\
\hline To & RA. Pollari & $\begin{array}{l}T \text { Hikido } \\
\text { GR Hoenes }\end{array}$ \\
\hline From & RA Walters Ron What & $\begin{array}{l}\text { RL Jones } \\
\text { WJ Madia }\end{array}$ \\
\hline Subject & $\begin{array}{l}\text { Investigation of } 331 \text { Building Barrel Incident } \\
\text { in Room } 175\end{array}$ & $\begin{array}{l}\text { JD Saffer } \\
\text { JE Trevino } \\
\text { JY Young } \\
\text { File/LB }\end{array}$ \\
\hline
\end{tabular}

You are hereby appointed as chair of a board to investigate the incident that occurred January 10, 1995 at the 331 building. The following personnel are appointed as members of the board:

T Hikido, Performance Assurance Department

RL Jones, Haste Management Section

JY Young, Toxicology Department

The RL Site Representative, JE Trevino, has been informed of the investigation and is also to be included on all board activities as an observer. Please provide Mr. Trevino a schedule of all board activities and a copy of your report.

The investigation is to employ a formal method of root cause anaiysis lead by Roger Pollari, a certified accident investigator. That report should identify the methodology used and the results of the analysis, fully explaining the technical elements of the causal sequence along with a description of the barriers that should have or could have prevented the occurrence. Appropriate recommendations for correction actions will be required. I would appreciate a preliminary report by January 27.

If you have any questions or concerns, please call me on 375-4532.

RAW: taz 


\section{EXHIBIT B}

ROOM DIAGRAM 


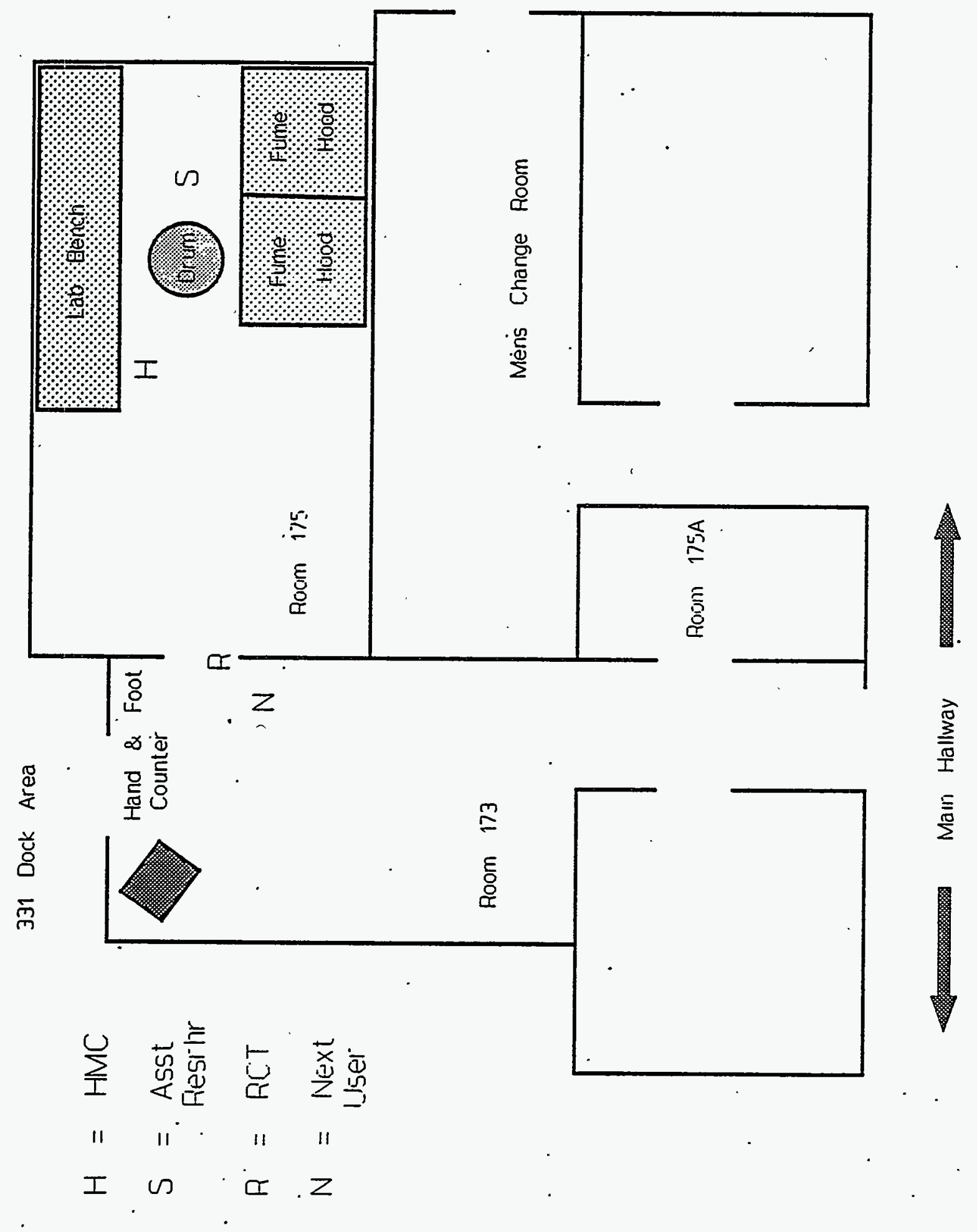


EXHIBIT C

PHOTOGRAPHS 


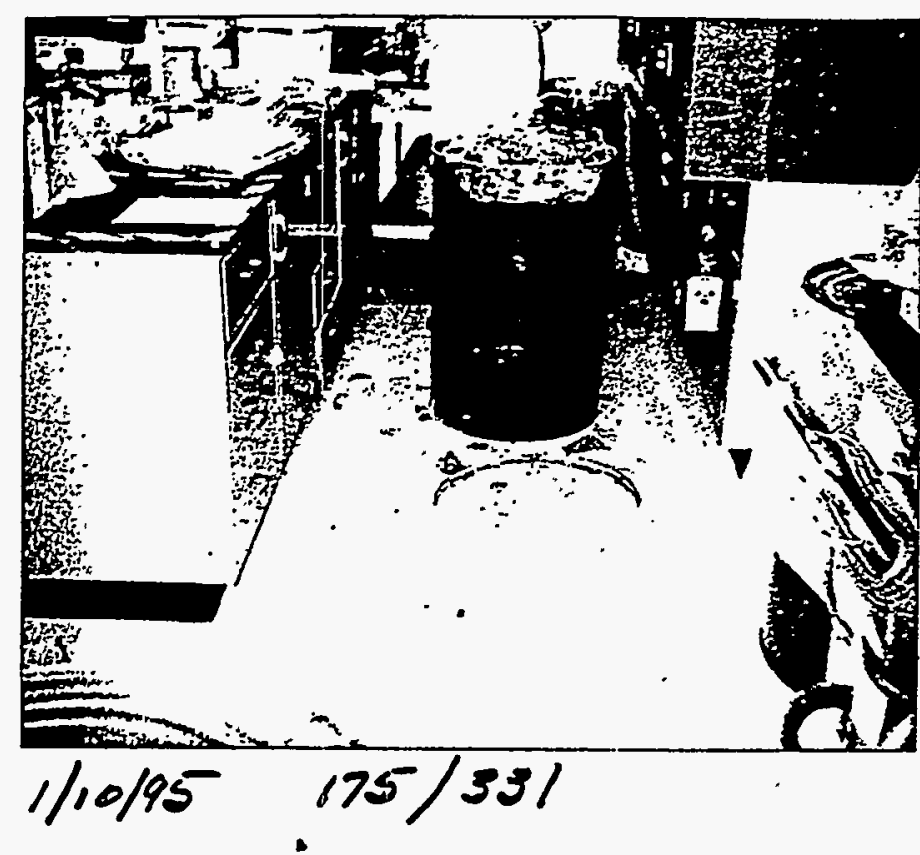

spees

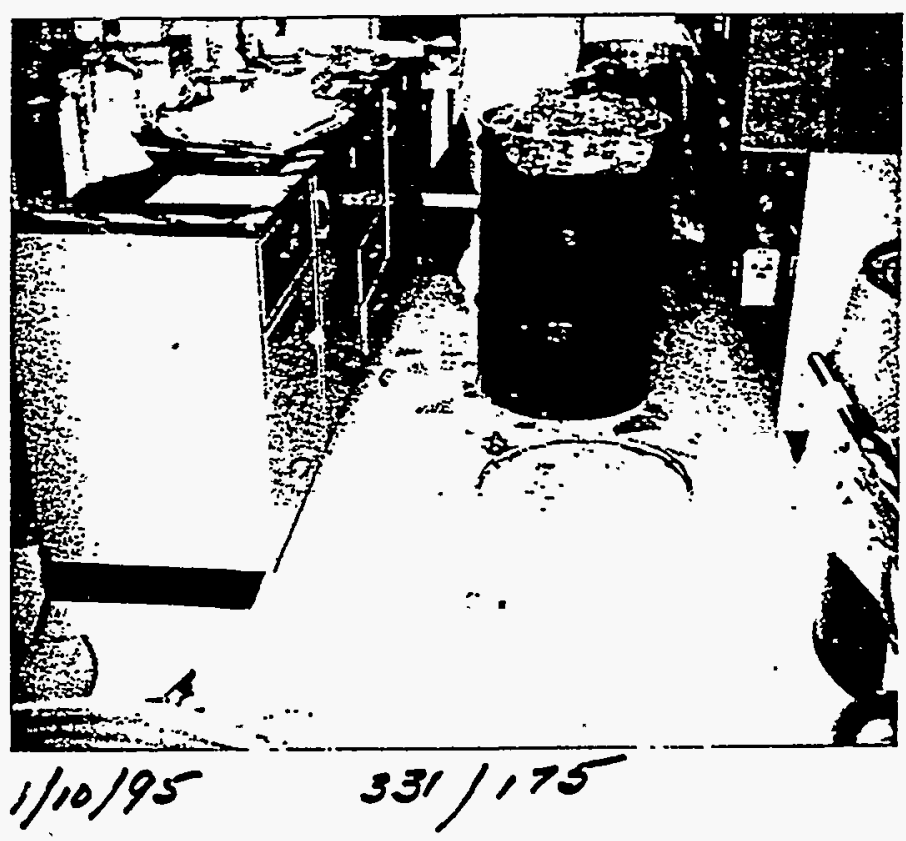

$S P, L C$

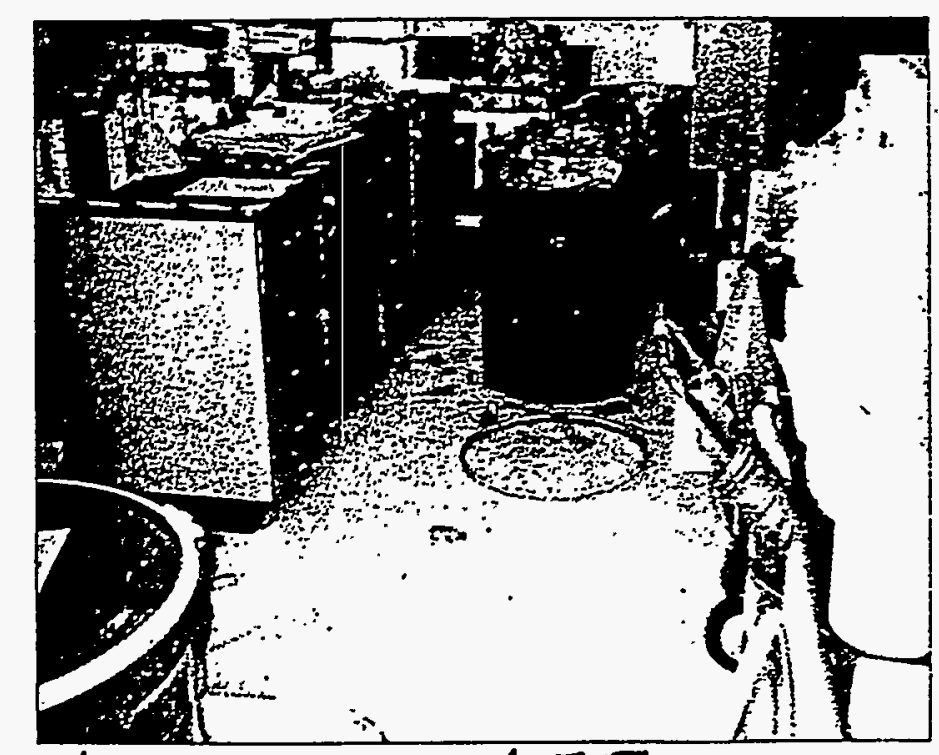

$1 / 10 / 95 \quad 331 / 175$

$$
\text { ipell }
$$

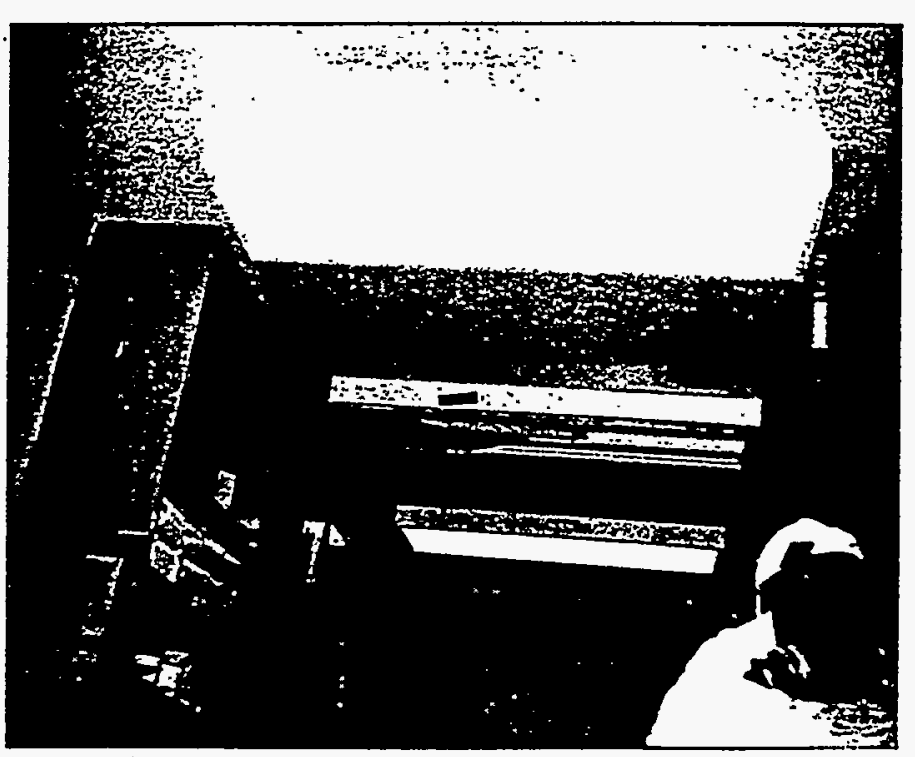

$1 / 10 / 95 \quad 351 / 175$

$s p, \angle<$ 
EXHIBIT D

NON-DESTRUCTIVE ASSAY (NDA) REPORT 
\%ัต Battelle

Pacific Northwest Laboratories

Project Number

Internal Distribution

File/LB

Date October 17, 1989

To Jerry Powers

From Ron Brodzinski

Row

Subject Barrel Assay

The data sheets from our assay of your drum are enclosed for your files. The following isotopes were quantitatively determined.

$$
\begin{aligned}
& { }^{237} \mathrm{~Np}=213 \mu g \\
& { }^{239} \mathrm{Pu}=142 \mathrm{mg} \\
& { }^{241} \mathrm{Pu}=521 \mu g \\
& { }^{244} \mathrm{Cm}=1.35 \mathrm{mg}
\end{aligned}
$$

In addition, the ${ }^{248} \mathrm{Pu}$ can be estimated based on the ${ }^{239} \mathrm{Pu} /{ }^{241} \mathrm{Pu}$ ratio. This. presumes that no ${ }^{24 i} \mathrm{Pu}$ has decayed. Hence for old material, the ${ }^{249} \mathrm{Pu}$ is essentially a lower limit:

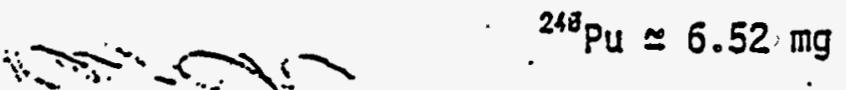

Don't hesitate to call if I can be of any additional help

RIB: $7 \mathrm{db}$

Enclosures

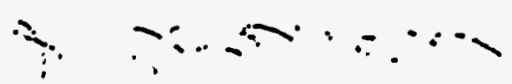

$\therefore \quad$.

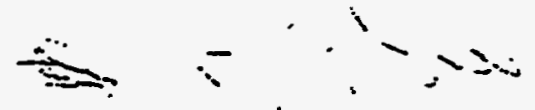




\section{EXHIBIT E}

RADIOLOGICAL SURYEY REPORT 


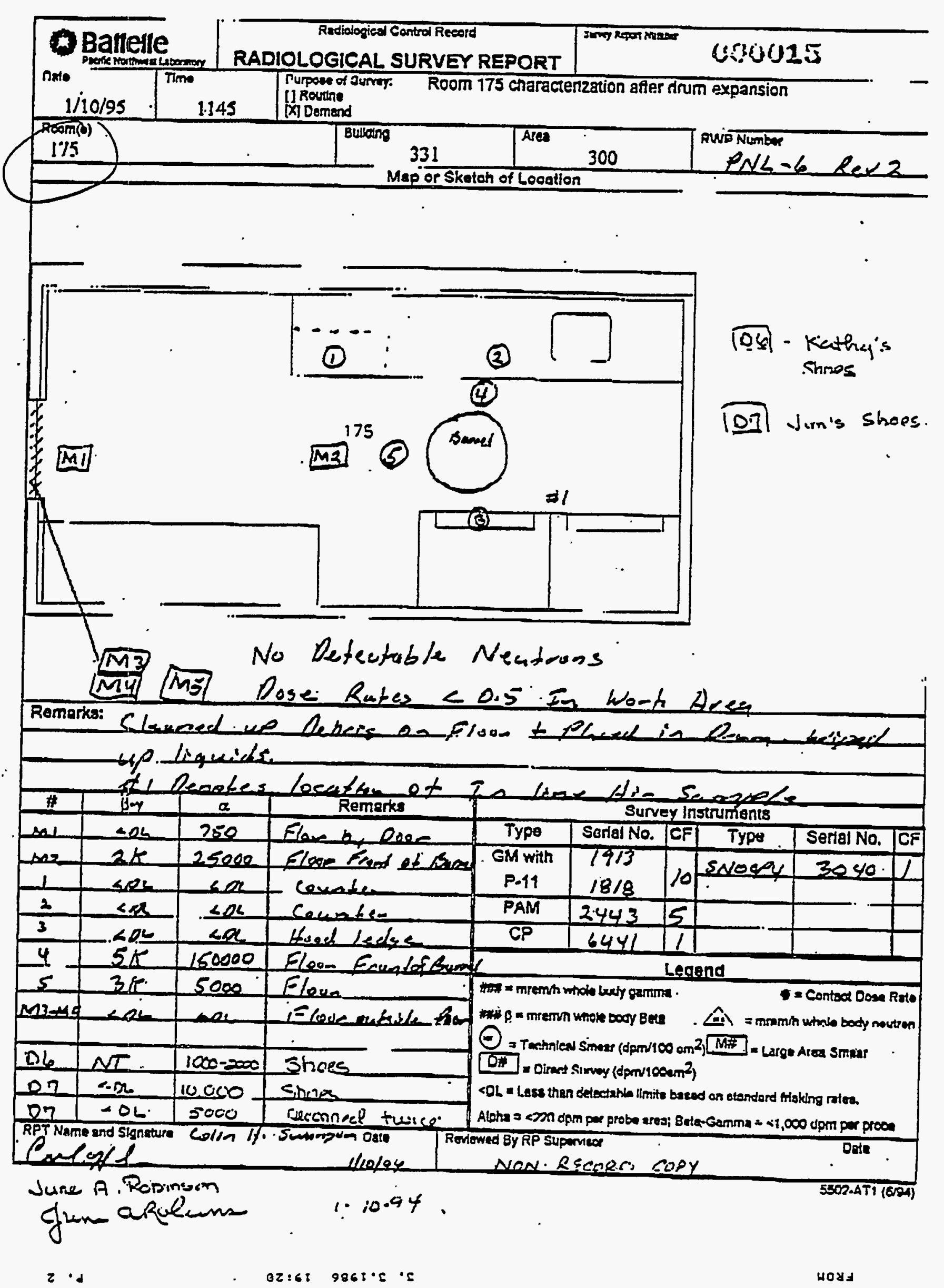




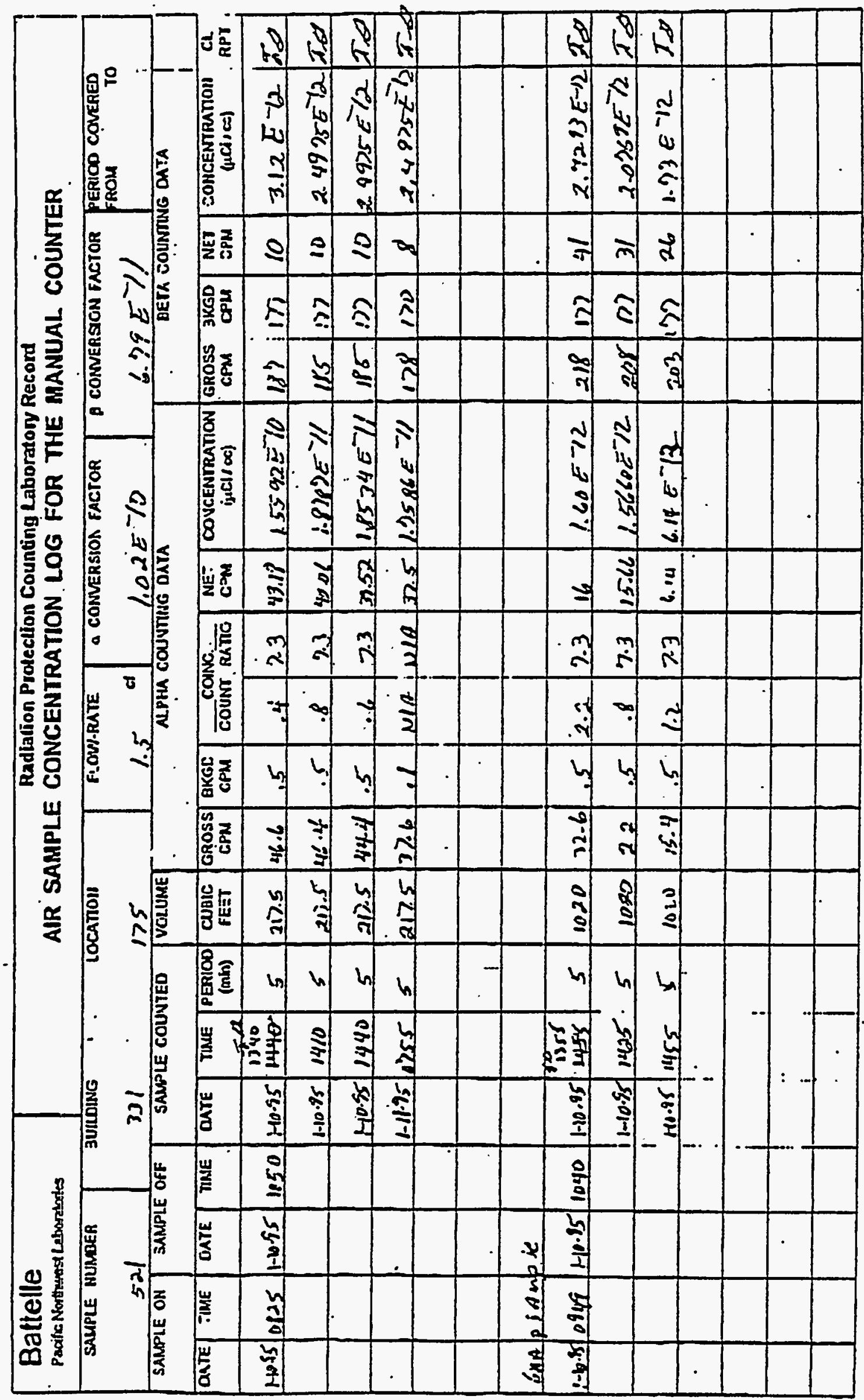




\begin{tabular}{|c|c|}
\hline Salte & $\begin{array}{c}\text { RADIATION PROTECTION COUNTINO LABORATORY RECORD } \\
\text { NASAL SMEAR REPORT FORM }\end{array}$ \\
\hline
\end{tabular}

Dalo: JANUARY 10,1995

Counter Localion (Birio) 3745 Counted By F. Gonzalez

Dackground Count (10 min.): $\alpha=$ 5 $\beta=$ 1772

Datection Levels:

$a=$ 6.76 $\beta=$ 66.1728

Counter Efficiency (counts por disintigratlen): $\alpha=$ .1939 $p=$ .2999

\begin{tabular}{|c|c|c|c|c|c|c|c|c|c|}
\hline \multirow{3}{*}{$\frac{\text { Namo }}{\text { JIM MORRIS }}$} & \multirow{3}{*}{$\frac{\text { Payroll Numbar }}{34725}$} & \multicolumn{4}{|c|}{ Smaxr Aeththy (dom) } & \multirow{2}{*}{\multicolumn{4}{|c|}{ Above Aollon Lovet? }} \\
\hline & & \multicolumn{2}{|c|}{ Lef Nostral } & \multicolumn{2}{|c|}{ Rhght Nostral } & & & & \\
\hline & & $-8 K G$ & 000 & & -0ra & & $\overline{7}$ & & \\
\hline KATHY LAUHALA & 38807 & $\angle A K C$ & -over & SOKC & -over & & $y$ & & $Y$ \\
\hline & & & & & & & & & $\boldsymbol{\Lambda}$ \\
\hline & & & & & & & & & \\
\hline & & & & & & & & & \\
\hline & - & & & & & & & & \\
\hline . & & & & & & & & & \\
\hline & & & & & & & & & \\
\hline & & & & & & & & & \\
\hline - & & & & & & & & & \\
\hline & & & & & & & & & \\
\hline
\end{tabular}
PHONE CONTACTS

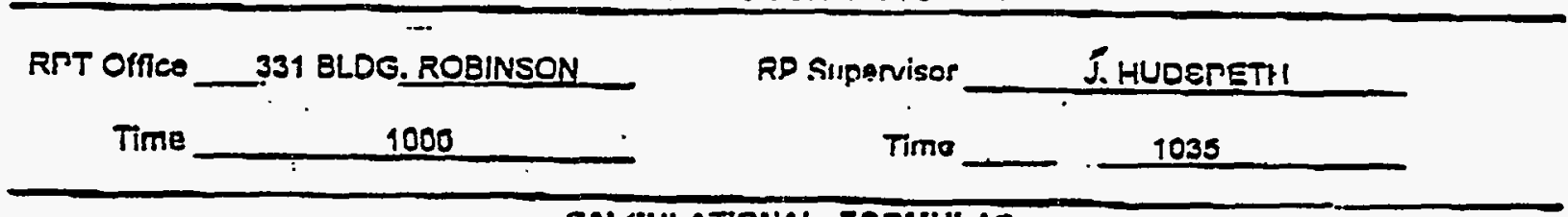
CALCULATIONAL FORMULAS

Dotection Limit $=\frac{2.71+1.65 \sqrt{C b(\text { counts })}}{E^{*}(1 U)} \quad$ Smoar Aetivity $-\left(C s \frac{C b)}{((10)(E))}\right.$

Where: $\quad C D$ a $10 \mathrm{~min}$. Backuround count $C s=10$ min. Smoar Count

Action Levais:

$E$ a Counter Efficiency (counts per disintigration)

Alona $=25 \mathrm{dpm}$ above detection level

Beta $=100$ upm above detection level.

Reviewed By: 2 rescis Data:

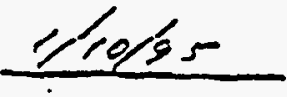




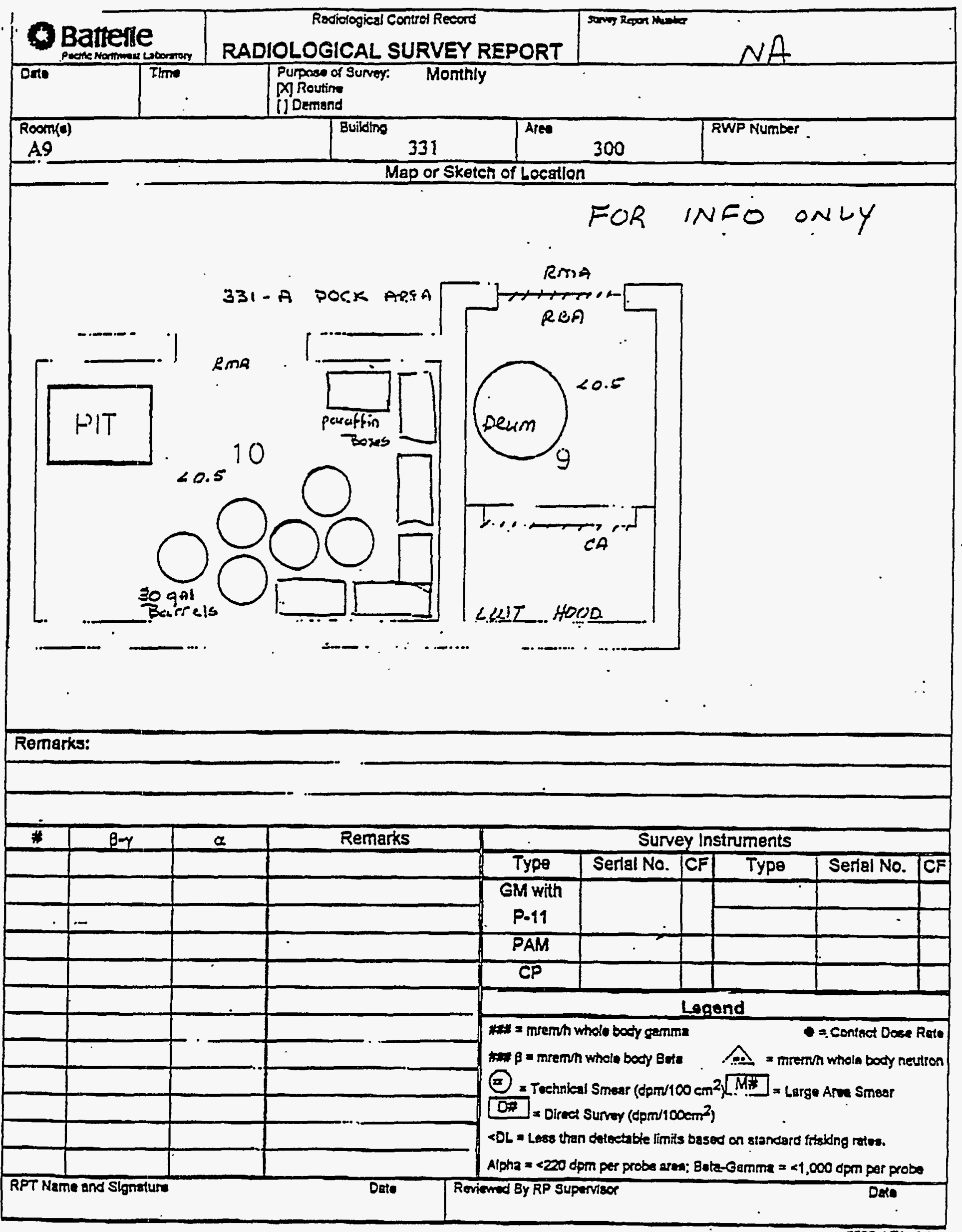




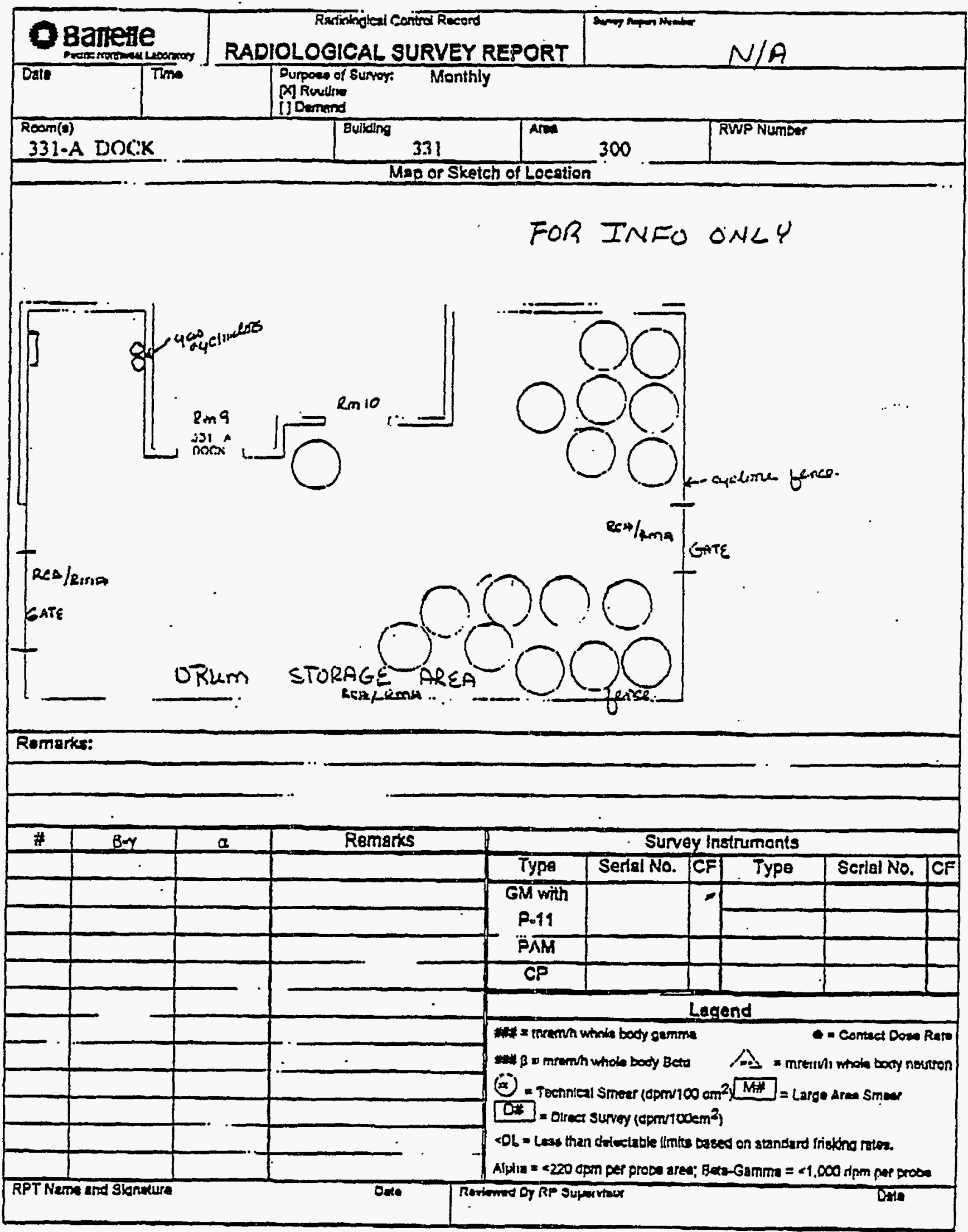


PNL 2400 REPORT 
OFFICIAL USE ONLY

PHL 2400 REPORT

REPORT \#: 95-003

DATE OF INCIDEHT: JANLLARY 10. 1995

TIME OF CALL: 0834:32

CRC ON OUTY: B WILLLIAMSON / KB KOCLIN

\section{DISTRIBUTION}

TD PARMAN

J8 SCHUETIE RR KING

RH GOUGH LR EBERHAPDT

RA POLLARI TO CHIKALLLA

GR HOENES JN HOLLOWAY

MR SUTHERLAND

BLDG MGR: RM ABRAHAM

INCIDENT: CONTAMINANT SPILL 331 QUILDING.

NOTIFIED BY: LA BRABY

CALLERS LOCATION: 331 BLDG

CALLERS PHONE A: $376-5685$

\begin{tabular}{|c|c|c|c|c|c|}
\hline CALIS PLACED BY CRC & IIME of CALL & (X) IF CONTACT & CALIS PLACED BY CRC & TIME OF CALL & (X) IF CONTACT \\
\hline PM ABRAHAM (BM) & $0838: 37$ & NO & J JACOBSON (RPT) & $0843: 49$ & $x$ \\
\hline RH ABRAHAM (BM) & 0839:06 & $X$ cELLLAR & L NELSON (RPT) & $0844: 16$ & NO - PAGED \\
\hline T HIKIDO (OC) & $0839: 22$ & NO - MESSAGE & L NELSON (RPT) & 0845:39 & $x$ \\
\hline T HIKIDO (OC) & $0843: 19$ & $x$ & RY GOUGH (SAFE) & $0846: 28$ & NO \\
\hline LA BRABY (FM) & $0834: 32$ & $X$ - NOTIFIED US & AG MINISTER (SAFE) & $0847: 00$ & $x$ \\
\hline \multirow[t]{2}{*}{ FJ WADE (RPT) } & $0843: 05$ & No & Q. HARVEY (PR) & $0842: 12$ & No \\
\hline & & $\bullet$ & G. HARVEY (PR) & 0850:51 & NO - PAGED \\
\hline
\end{tabular}

\section{SLPYARY}

ON JANUARY 10. 1995 AT 0834:32 HOURS. LA BRABY CALLED THE CONTROL ROOM AND ADVISED THAT A LOH LEVEI WASTE CONTAINER . HAD BEEN GROUGHT INTO THE 331 BUILDING. ROOM 175. THIS WAS tO CHECK THE PACKAGING. DUE tO tHE TEMPERATURE CHANGE THE LID POPPED OFF THE CONTAINER ALLOWINE A SMALL AMOUNT OF AMERICIUM AND PLUTONILM TO ESCAPE. THERE WAS A RPT PRESENT. T HIKIDO (OC) QLASSIFIED THIS AS A OFF NOPMAL OCCURRENCE. THE ABOVE STAFF WERE NOTIFIED. 


\section{EXHIBIT $G$}

RADIOLOGICAL HORK PERMITS 


\section{2 \\ HANFORD RADIOLOGICAL WORK PERMIT}

CONTRACTOR:

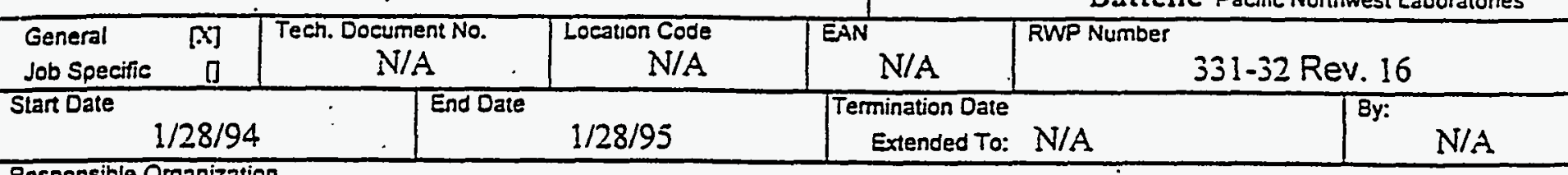

Responsible Organization

Biology and Chemistry, Cellular and Mammalian Biology, D7A25

Job Loeation

Room 175 and 175A; 331 Building; 300 Area

Job Description and Type of Area: Radiation Area, Radioactive Material;

Storage of Radionuclides in rooms 175 and 175A. Receiving and unpacking of radioactive shipments in 175.

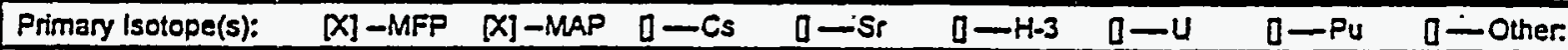

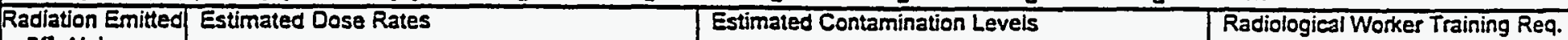

[X] Alpha

(x) Beta

General Area:

$10 \mathrm{mrem} / \mathrm{h}$

[X] Photons

i] Neutrons

Maximum Contact

$25 \mathrm{mrem} / \mathrm{h}$

Beta-gamma:

$<1,000 \mathrm{dpm} / 100 \mathrm{~cm}^{2}$

Alpha:.

$.020 \mathrm{dpm} / 100 \mathrm{~cm}^{2}$

I....... []

II...... [X]

Intemal Dosimetry Requirements (for routine work under this RWP. except those entering for observation only)

$[X]$-Annual Whole Body Count $\square$ - Lung Count $\square$-Urinalysis Isotopes to Test for (if any):

MINIMUM RADIOLOGICAL PROTECTION REQUIREMENTS

- Entry for observation:

Internittent RPT coverage / Basic TLD / Lab coat

- Transfer of between rooms 175 and 175A:

Intermittent RPT coverage / Multipurpose TLD / Lab coat /

Surgeon's gloves

- Shipping and Receiving radioactive shipments:

Continuous RPT coverage / Multipurpose TLD / Lab coat

- Unpacking radioactive shioments:

Continuous RPT coverage / Multipurpose RD / Lab coat /

Surgeon's gloves
SPECIAL INSTTRUCTIONS (SI)

1. For off shift RPT coverage contact the RP Duty Supervisor at 3762244, or page 546-6298. Emergencies contact Battelle Emergency at $375-2400$.

2. This RWP is limited to conditions where general area dose rates are $<50 \mathrm{mrem} / \mathrm{h}$ and/or contamination levels $<1,000 \mathrm{dpm} / 100 \mathrm{~cm}^{2}$ beta-gamma or $<20 \mathrm{dpm} / 100 \mathrm{~cm}^{2}$ alpha. Airbome radioactivity levels are limited to $10 \%$ DAC. If any of these levels are exceeded, a new or revised RWP is required.

3. Receptacie containing radionuclides shall not be opened in Room 175A. Sealed Radionuclide containers shall be moved to Room 175 prior to removal of any material in any container.

4. Cabinets containing radionuclides shall be appropriately posted.

5. 175 and $175 \mathrm{~A}$ shall be locked when the room is not occupied.

6. Materials for storage shall be triple packaged. The outer container shall be metal, free of removable contamination and labeled as to dose rate, contamination, radioisotope, date, and RPT initials.

7. Periom a hand and foot survey for alpha and beta-gamma contamination prior to feaving Room 175.

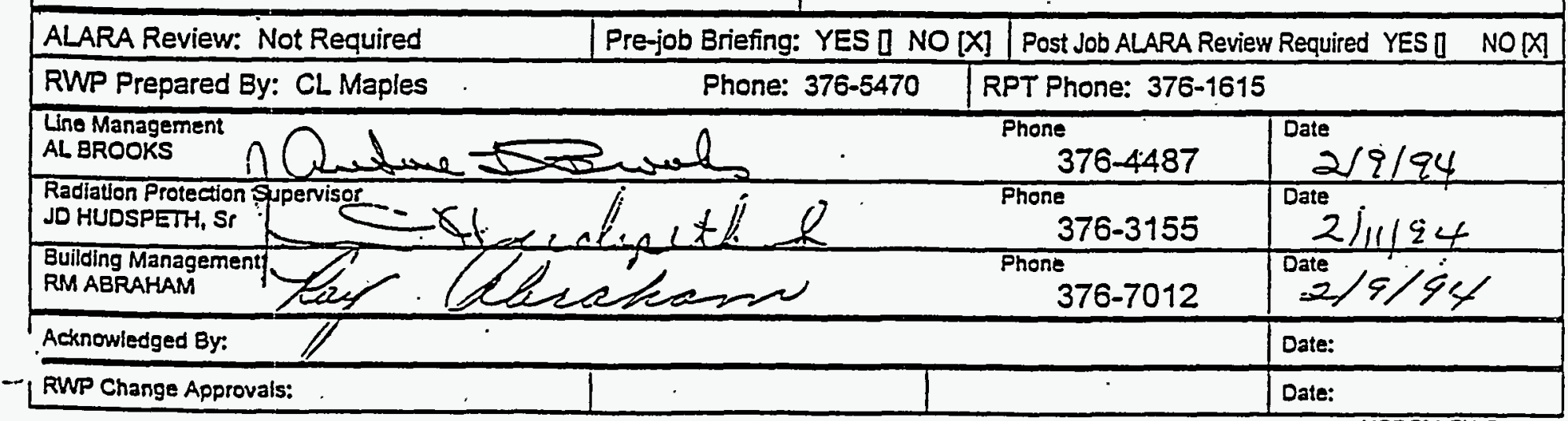

HSRCM-RWP (1/93) 


\section{ACKNOWLEDGMENT/REVIEW}

Page 2 of:
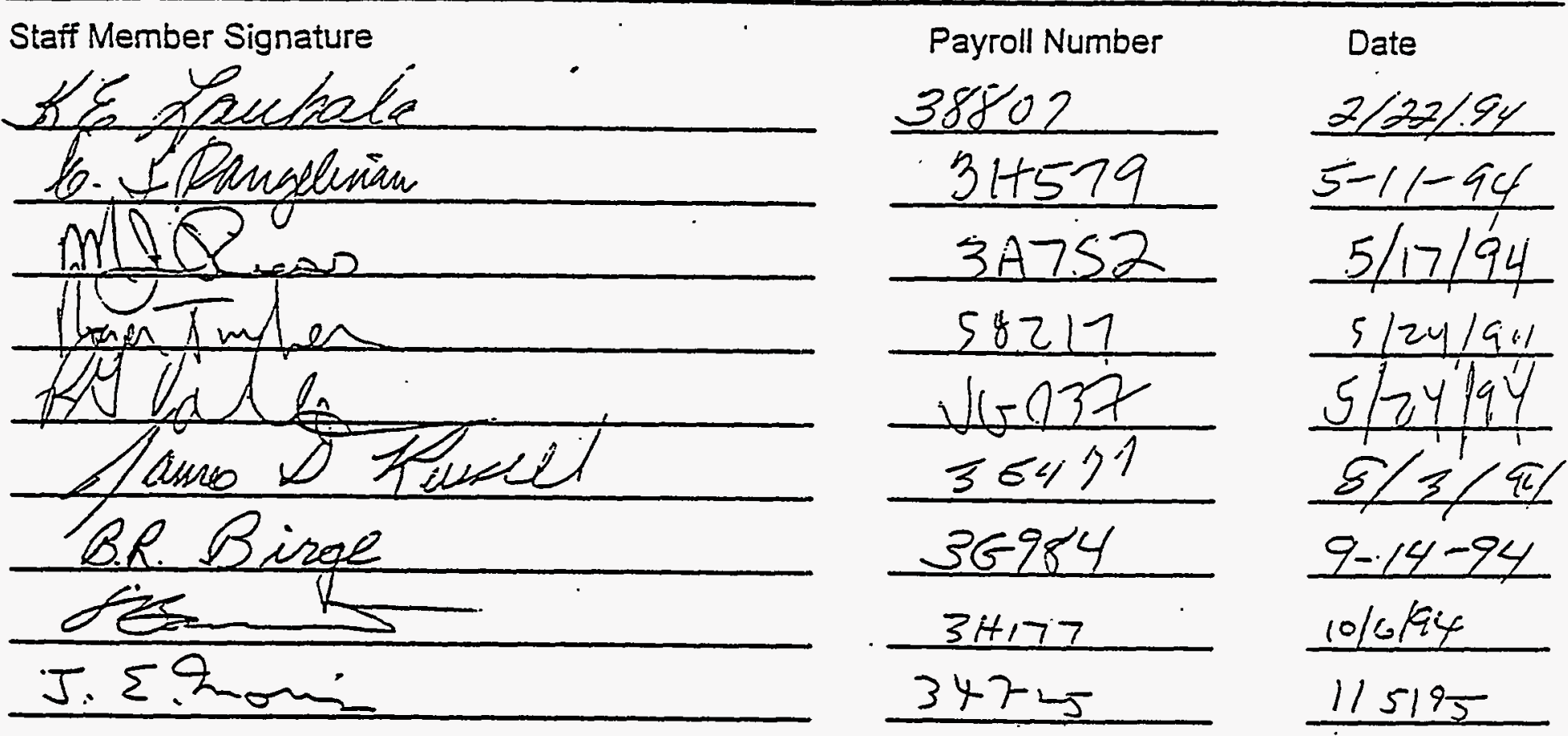

DO NOT remove or dispose of this page, it MUST be posted with the RWP it pertains to. Return this form to Radiological Control, MSIN P7-78, when this RWP expires, is voided, or is replaced with a new revision. 


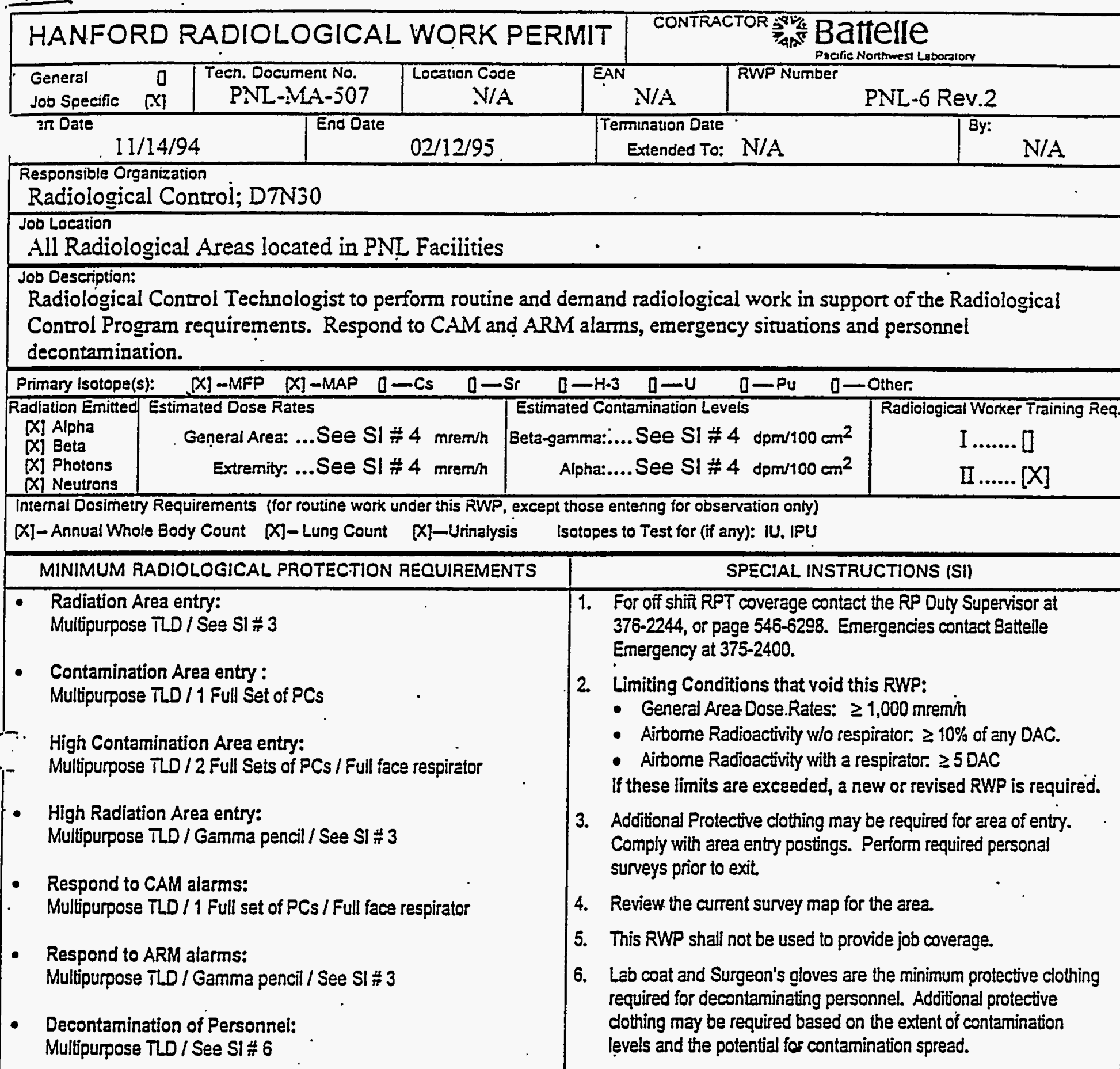




\section{REFERENCES}

\section{INDIVIDUALS INTERVIEWED:}

Kathy Lauhala, Hazardous Material Coordinator

Jim Morris, Assisting Researcher

June Robinson, RCT

Dennis Mahlum, Researcher Waiting in Room 173

Les Braby, Biology and Chemistry Department Manager

Jon Hudspeth, RCT's Supervisor

Joe Jacobsen, Radiological Control Section Manager

Ray Abraham, 331 Building Manager

OTHER INDIVIDUALS CONTACTED:

Ron Brodzinski, Nondestructive Assay

Andrea Taylor, Laboratory Safety Trainer (RAD worker training)

Ray Kofoed, Single Point Contact (SPC) Consultant

Andy Minister, Laboratory Safety Representative contacted by SPC

Teresa Zinn, Executive Assistant, Life Sciences Center

Laboratory Training Coordination (for training records)

DOCUMENTS REVIEHED:

RADIOLOGICAL HORK PERMITS:

RHP $\$ 331-32$, Rev.16

RHP \#PNL-6

ASSESSMENTS/SURVEILLANCES

PNL response to the Dames and Moore report, PACIFIC NORTHWEST LABORATORY (PNL) BUILDING 331 RESOURCE CONSERVATION AND RECOVERY ACT (RCRA) ASSESSMENT, PNL-CC95-0030. Response dated October 31, 1994.

PNL report, CONDUCT OF OPERATIONS ASSESSMENT-331 FACILITY, dated September 1994

TRAINING RECORDS

Kathy Lauhala, Hazardous Material Coordinator (HMC)

Jim Morris, Assisting Researcher

PNL MANUALS

PNL-MA-5, Nuclear Material Control and Accountability

PNL-MA-6, PNL Radiological Control Manual

PNL-MA-7, Off-Normal Event Reporting System

PNL-MA-8, Waste Management and Environmental Compliance

PNL-MA-11, Emergency Preparedness

PNL-MA-41, PNL ES\&H Management Self-Assessment Program

PNL-MA-43, Industrial Hygiene, Occupational Safety, and Fire Protection Programs

PNL-MA-50, PNL Operations Manual 